\title{
I SIMPÓSIO DE \\ REDUÇÃO DO RISCO \\ DE DESASTRES NA \\ REGIÃO NORDESTE
}

II WORKSHOP DO GRUPO DE PESQUISA EM GERENCIAMENTO DOS RISCOS E DESASTRES NATURAIS 


\section{APRESENTAÇÃo}

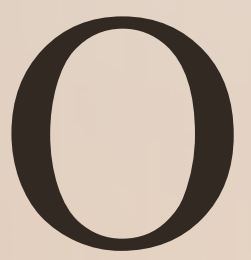

presente dossiê é fruto das discussões acadêmicas travadas no âmbito do I Simpósio de Redução do Risco de Desastres na Região Nordeste e II Workshop do Grupo de Pesquisa em Gerenciamento dos Riscos e Desastres Naturais, ambos, realizados em conjunto, no Centro Regional de Ensino Superior do Seridó da Universidade Federal do Rio Grande de Norte, localizado na Cidade de Caicó, "Capital do Seridó".

$\mathrm{Na}$ oportunidade, contamos com a participação de pesquisadores e membros da defesa civil de diversos estados da região nordeste. Optamos por seguir uma dinâmica diferente da primeira versão do evento, realizado no ano 2017. Destarte, seguiu-se um formato de mesas redondas, mais típico de simpósios, intercaladas com oficinas desenvolvidas por pesquisadores (docentes e discentes) do GENAT, além de apresentações orais de trabalhos acadêmicos aprovados para publicação.

Nessa versão tradicional do evento bianual do GENAT, foram discutidas temáticas atuais, que vêm contribuindo para o aperfeiçoamento das ações de gestão do risco de desastres nas grandes e médias cidades do nordeste brasileiro, abordando o tema geral: Vulnerabilidade Socioambiental na Região Nordeste: Novas Perspectivas e Ações de Planejamento Urbano-Territorial.

A ocorrência de diversos desastres no cenário nacional e mundial tem alertado para a adoção de novas medidas de prevenção.
Isso significa dizer, por exemplo, que os gestores públicos, sobretudo das cidades em fase de expansão, precisam direcionar suas ações com base nas catástrofes ocorridas, de modo a eliminar possíveis recorrências. Além disso, aqueles administradores de cidades grandes, onde os desastres são recorrentes, precisam adotar medidas, não apenas de remediação, mas de reestruturação do espaço urbano. Nesse ínterim, o planejamento e ordenamento territorial são ações indispensáveis para o desenvolvimento urbano sustentável, por meio do qual o bem-estar social deve ser o principal pilar.

Os estudos aqui apresentados abordam temáticas diversas, com grande convergência para ações de redução do risco de desastres, tratando, do estudo do clima e dos processos geomorfológicos em ambiente semiárido. Não é por uma mera casualidade que esses estudos vêm sendo feitos, mas por urgências que as cidades semiáridas vêm enfrentando. Embora pareça uma antítese, os principais problemas envolvem, não só prolongados períodos de secas, mas alagamentos e inundações, embora mais restritas temporalmente e espacialmente. Ambos chamam a atenção, pois oferecem elevado risco às populações "sertanejas". No caso específico das secas, importa suas causas e consequências, estudadas sob variadas óticas. Do ponto de vista geomorfológico, interessa suas repercussões sobre o regime de erosão/sedimentação e sua influência sob a mudança dos níveis de base locais, que impõem forte pressão sobre a disponibilização de recursos hídricos. 
No caso específico da climatologia, estuda-se séries temporais anuais e rítmicas, considerando elementos do clima outrora pouco abordados, a exemplo da evapotranspiração.

Em áreas urbanas, também chama atenção temáticas novas, tais como o desgaste de conjuntos arquitetônicos pela ação climática, e a influência da evolução de sistemas cársticos. Sobre o carste, por exemplo, não se observava que essas feições oferecessem tanto risco às populações das grandes cidades, onde o sobrepeso das edificações e a destinação incorreta de águas servidas passam a oferecer sérios riscos de subsidência do solo urbano.

Assim, compreende-se, agora, que essas temáticas urgem no escopo de planos de contingência, planos diretores e outros documentos importantes para a gestão das cidades do nordeste brasileiro.

Prof. Dr. Saulo Roberto de Oliveira Vital Líder do GENAT. 